\title{
Irrigation and lithothamnium fertilization in bell pepper cultivated in organic system
}

\author{
Adão W. P. Evangelista ${ }^{1}$, André R. M. de Sá ${ }^{1}$, José Alves Júnior ${ }^{1}$, \\ Derblai Casaroli ${ }^{1}$, Wilson M. Leandro ${ }^{1} \&$ Jorge L. M. de Souza ${ }^{2}$ \\ ${ }^{1}$ Universidade Federal de Goiás/Setor de Engenharia de Biossistemas/Programa de Pós-Graduação em Agronomia. Goiânia, GO. E-mail: awpego@pq.cnpq.br \\ (Corresponding author); andre.roure@hotmail.com; jose.junior@pq.cnpq.br; casaroli@agro.ufg.br; wilsonufg@gmail.com \\ ${ }^{2}$ Universidade Federal do Paraná/Departamento de Solos e Engenharia Agrícola/Programa de Pós-graduação em Ciências do Solo, Curitiba, PR. E-mail: \\ jmoretti@ufpr.br
}

Key words:

Capsicum annuum L.

marine input

soil water potential

\begin{abstract}
A B S T R A C T
For proper plant growth and achievement of satisfactory yield, it is essential to replenish water and nutrients, in the right amount and time. Therefore, the aim of this study was to evaluate the effects of soil water potential and lithothamnium doses on the growth and yield of bell pepper fruits in an organic production system. The experimental design was randomized blocks in a $5 \times 4$ factorial scheme, with four replicates. The treatments were five lithothamnium doses $\left(0,0.5,1,2\right.$ and $\left.4 \mathrm{~g} \mathrm{dm}^{-3}\right)$ and four soil water potentials $(-6,-24,-42$ and $-60 \mathrm{kPa}$ ). Increasing lithothamnium doses and irrigations based on increasing soil water potentials produced linear increase in plant growth and fruit production. The maximum economic efficiency of the lithothamnium fertilizer was obtained with the application of $0.54 \mathrm{~g} \mathrm{dm}^{-3}$, corresponding to the fruit yield of $491.26 \mathrm{~g} \mathrm{plant}^{-1}$. More frequent irrigations favor the increase in growth and yield of bell pepper in organic system.
\end{abstract}

\section{Palavras-chave:} Capsicum annuum L. insumo marinho potencial de água no solo

\section{Irrigação e adubação com lithothamnium do pimentão cultivado sob sistema orgânico}

\begin{abstract}
R E S U M O
Para o desenvolvimento adequado da planta e obtenção de produtividade satisfatória é essencial a reposição de água e nutrientes na quantidade ideal e no momento oportuno. Ante o exposto objetivou-se, neste trabalho, avaliar os efeitos de níveis de potencial de água no solo e doses de lithothamnium sobre o crescimento e a produção de frutos de pimentão cultivado em sistema de produção orgânico. O delineamento experimental foi o de blocos ao acaso em arranjo fatorial $5 \mathrm{x} 4 \mathrm{com}$ quatro repetições. Os tratamentos corresponderam à aplicação de cinco doses de lithothamnium $\left(0 ; 0,5 ; 1 ; 2 \mathrm{e} 4 \mathrm{~g} \mathrm{dm}^{-3}\right)$ e quatro potenciais de água no solo $(-6,-24,-42$ e $-60 \mathrm{kPa})$. A aplicação de doses crescentes de lithothamnium e irrigações manejadas com base em valores crescentes de potenciais de água produziram aumento linear nas características de crescimento e produção do pimentão. A máxima eficiência econômica do fertilizante lithothamnium foi obtida com a aplicação da dose de $0,54 \mathrm{~g} \mathrm{dm}^{-3}$ correspondendo à produção de frutos de 491,26 $\mathrm{g} \mathrm{planta}^{-1}$. Irrigações mais frequentes favorecem o aumento do crescimento e da produtividade do pimentão cultivado sob sistema orgânico.
\end{abstract}




\section{INTRODUCTION}

Bell pepper cultivation in organic production system has stood out among the producers in Brazil, especially for the increase in the quality of the product and achievement of good prices in the market. In order to achieve these results with the crop, the adequate planning of the production system is necessary using efficient agricultural practices, such as irrigation (Carvalho et al., 2011; Lima et al., 2012).

The correct irrigation management to obtain economically viable yield is that in which water is applied in the soil at the right time and in amount sufficient to meet crop water requirements, using methods that determine the availability of water in the soil for the irrigated crop, such as tensiometry (Leão et al., 2007).

Various studies have been conducted to determine the minimum value that the soil water potential may reach in order not to cause reduction in bell pepper yield. The results are variable and, in general, show that irrigation management based on soil water potentials between -10 and $-15 \mathrm{kPa}$ favors the increase in crop growth and yield (Araújo et al., 2010; Carvalho et al., 2013).

Besides the correctly managed irrigation, the supply of nutrients to plants through fertilization directly interferes with the process of agricultural production. In this context, it is important to know the factors that influence the availability of nutrients to plants with the use of new inputs, such as the organic fertilizer lithothamnium, derived from calcareous marine algae, which has in its composition calcium carbonate, magnesium and more than 20 microelements (Dias, 2010). Research results with this fertilizer are still incipient, especially when associated with irrigation, and this technique can optimize the use of the fertilizer (Aquino et al., 2012).

This study aimed to evaluate the effects of levels of soil water potential and doses of lithothamnium on the growth and fruit production of bell pepper cultivated in organic production system.

\section{Material AND Methods}

The experiment was carried out in the experimental area $\left(70 \mathrm{~m}^{2}\right)$ of the School of Agronomy of the Federal University of Goiás, in Goiânia, GO, Brazil, in a greenhouse equipped with an automatic control and data acquisition system of temperature and relative air humidity.

The experimental design was randomized blocks in a $5 \times 4$ factorial scheme (doses $\mathrm{x}$ potentials) with four replicates. The treatments consisted of five doses of lithothamnium $(0,0.5,1$, 2 and $4 \mathrm{~g} \mathrm{dm}^{-3}$ of soil) and four soil water potentials $(-6,-24$, -42 and $-60 \mathrm{kPa}$ ).

Bell pepper seedlings, hybrid 'Supremo', were transplanted to $14-\mathrm{dm}^{-3}$ pots on September 1, 2014, 60 days after sowing when the seedlings had five to six leaves and approximate height of $0.10 \mathrm{~m}$. Initially, all the plots were manually irrigated, which guaranteed $100 \%$ of success in seedlings growth. After 15 days of transplantation, water management started to be performed according to the treatments when the plants showed the same number of leaves and height of the transplanting period. Plants were irrigated using a drip system. Soil water potential was monitored through the installation of three Watermark sensors per treatment at depth of $0.15 \mathrm{~m}$, which were connected to a data logger programmed to store data of soil water potential at intervals of $1 \mathrm{~h}$.

Soil water retention curve was determined using soil samples collected in the plots, fitted using the model of Genuchten (1980) and the soil water content corresponding to field capacity was determined using the method of soil saturation, verified through the stoppage of drainage from the pots.

Irrigation management was performed based on the monitoring of soil water potential, corresponding to each treatment. The applied volume of water was calculated based on the soil water retention curve and the irrigation time was calculated so as to increase soil moisture to the value corresponding to field capacity.

At 104 days after transplantation of the seedlings, the following growth characteristics were evaluated: plant height, stem diameter, number of leaves and leaf length and width. With the data of leaf length and width, the leaf area index was estimated according to Benincasa (2003). At the end of the experiment, plants were harvested and separated into stem, leaves and roots, for later determination of the dry matter of these parts.

For production evaluation, the fruits were harvested green, while the number of fruits per plant and the mass of each fruit were determined at harvest, totaling five evaluations. Nitety percent of maximum yield was considered as the maximum technical efficiency, thus calculating the economic dose of lithothamnium (Melo \& Furtini Neto, 2003).

The obtained data were subjected to analysis of variance and, when there were significant differences, regression analyses were performed and the degrees of freedom of the treatments were decomposed into polynomial regression components, opting for the model with highest degree of significance.

\section{RESUlts AND Discussion}

During the crop cycle, the total water depth applied and the mean irrigation intervals of the treatments with irrigation at the potentials of $-6,-24,-42$ and $-60 \mathrm{kPa}$ were $537,446,387$ and $372 \mathrm{~mm}$ and 1, 2.5, 4 and 5 days, respectively, indicating that irrigations based on lower potentials provided more water to the crop and were more frequent, guaranteeing soil moisture close to field capacity during the entire experimental period.

There were significant effects of irrigation management on plant height, stem diameter, leaf area index, dry mass of leaf, stem and root. Leaf and root dry matters were influenced by the fertilization treatment. There was no significant effect between irrigation and fertilization doses for the evaluated growth variables.

Plant height, stem diameter, leaf area index and leaf dry mass showed positive linear response to the soil water potentials (Figures 1A, 1B, 1C and 1D). In the comparison between the values obtained for irrigations based on the potentials of -6 and $-60 \mathrm{kPa}$, there was a reduction of $11 \%$ in plant height and $20 \%$ in stem diameter (Figures 1A and 1B).

The results indicate that plants irrigated with lower potential may have been subjected to water deficit. According to Lacerda 

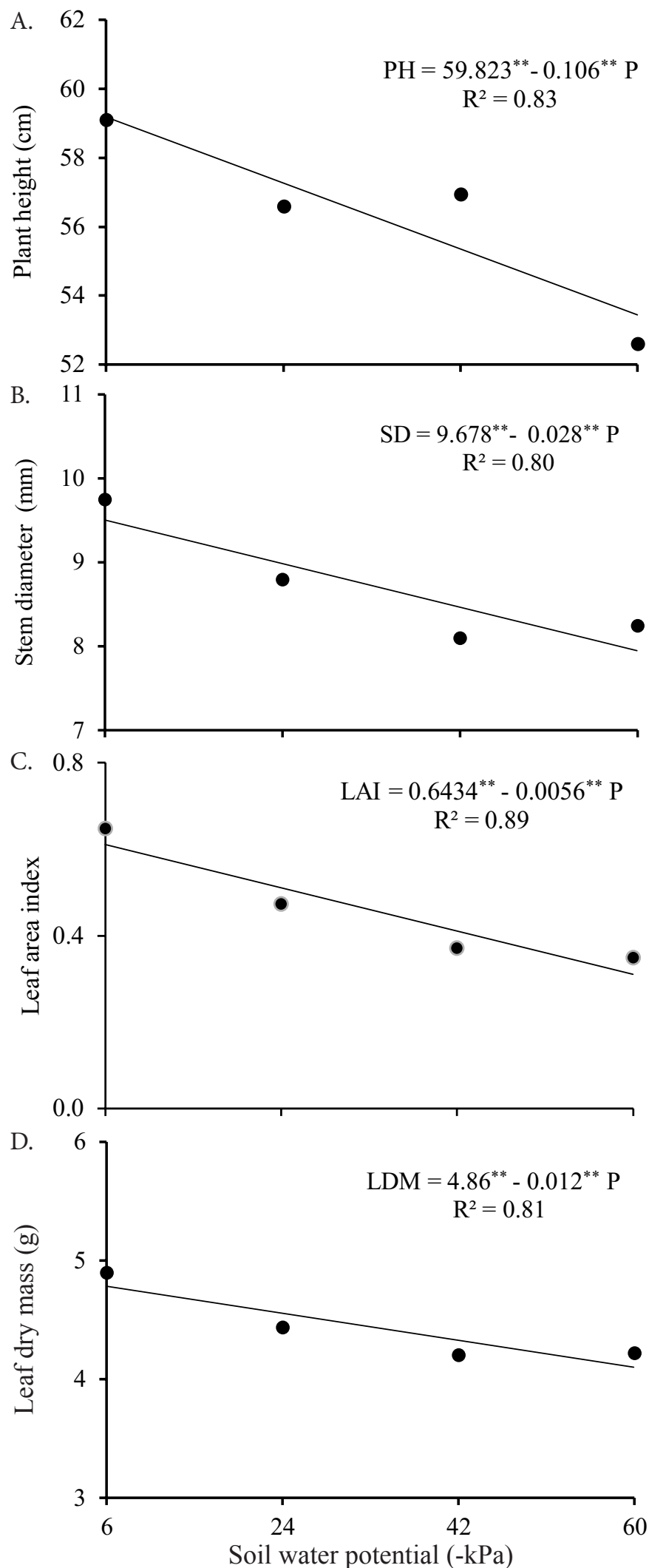

Figure 1. Plant height - PH (A), stem diameter - SD (B), leaf area index - $\mathrm{LAI}(\mathrm{C})$ and leaf dry mass - LDM (D) as a function of soil water potentials

et al. (2007), water deficit affects plant growth for inducing the reduction of photosynthetic activity, compromising cell expansion and division in the stem meristems and also promoting hormonal alterations in the plants with consequent reduction in growth.

The leaf area index of plants irrigated with the treatment of $-6 \mathrm{kPa}$ was $97 \%$ higher than that in the treatment of -60
$\mathrm{kPa}$ (Figure 1C). The reduction of leaf area index in plants irrigated with lower water potentials is also a reaction of the plant to the water deficit (Taiz \& Zeiger, 2004), a result of the reduction of both the size of individual leaves and the lower leaf production (Santos \& Carlesso, 1998). The inhibition of leaf expansion, due to the reduction in the cell division and expansion rate, results in smaller canopy, which is an indication of morphological adaptation of the plant to prevent water losses to the environment through transpiration (Lacerda et al., 2007).

Leaf dry matter was also reduced when plants were subjected to a higher water deficit (Figure 1D). It should be pointed out that the most expressive responses of the plants to water deficit occurred in the leaves, with consequent decrease in leaf area, stomatal closure, acceleration of senescence and leaf abscission (Cantuário et al., 2014). In this study, plants subjected to the highest level of water deficit, despite their lower leaf area index and leaf dry matter, did not show characteristics of senescence or high rate of abscission. Probably, the higher resistance to senescence and leaf abscission is due to the fact that the plants suffered a gradual water deficit since the beginning of the cycle, facilitating the adaptation, because early senescence and fall of leaves are usually triggered in plants cultivated under adequate conditions of water supply that suddenly suffer with water deficit (Santos \& Carlesso, 1998). Therefore, their morphophysiological mechanisms are severely affected, requiring rapid adaptation to the new situation.

The response of stem and root dry mass in relation to soil water potentials was similar to that observed for leaf dry matter (Figure 2). The coincidence of response of these variables is due to the influence of water availability on the potential growth of the plant canopy and on the photosynthetic activity. Thus, the entire plant development, including stem and root growth and even yield, is affected.

Leaf dry matter responded positively to the application of lithothamnium doses and the variable most influenced by the input was root dry matter, with increment of $104 \%$ for the application of the best dose (Figure 3 ). The higher production of root dry mass in plants fertilized with lithothamnium can be attributed to a probable increase in the formation of secondary roots by the plant due to the better nutritional conditions promoted by the input. Lithothamnium is a fertilizer with high

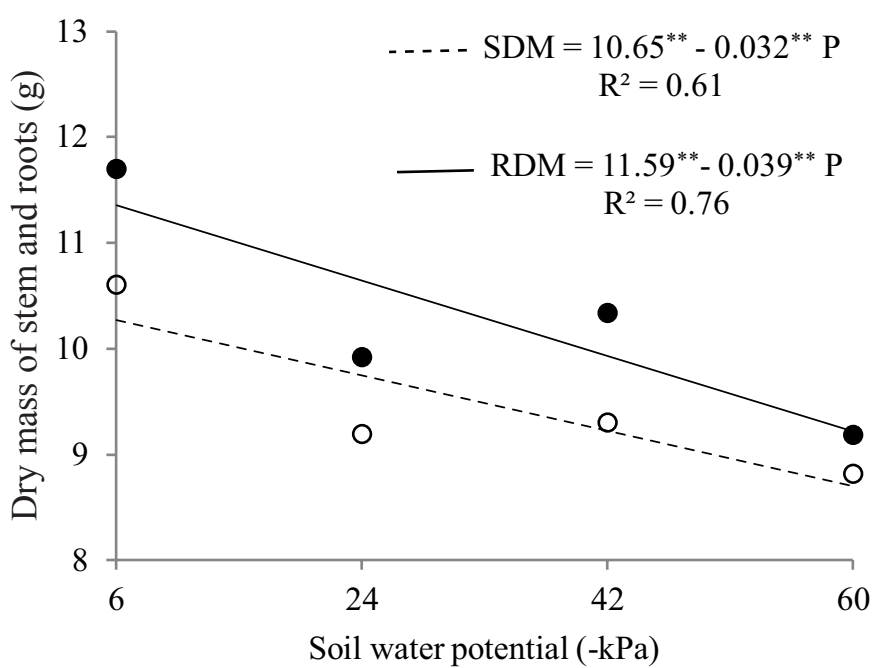

Figure 2. Dry mass of stem (SDM) and root (RDM) of bell pepper as a function of soil water potentials 


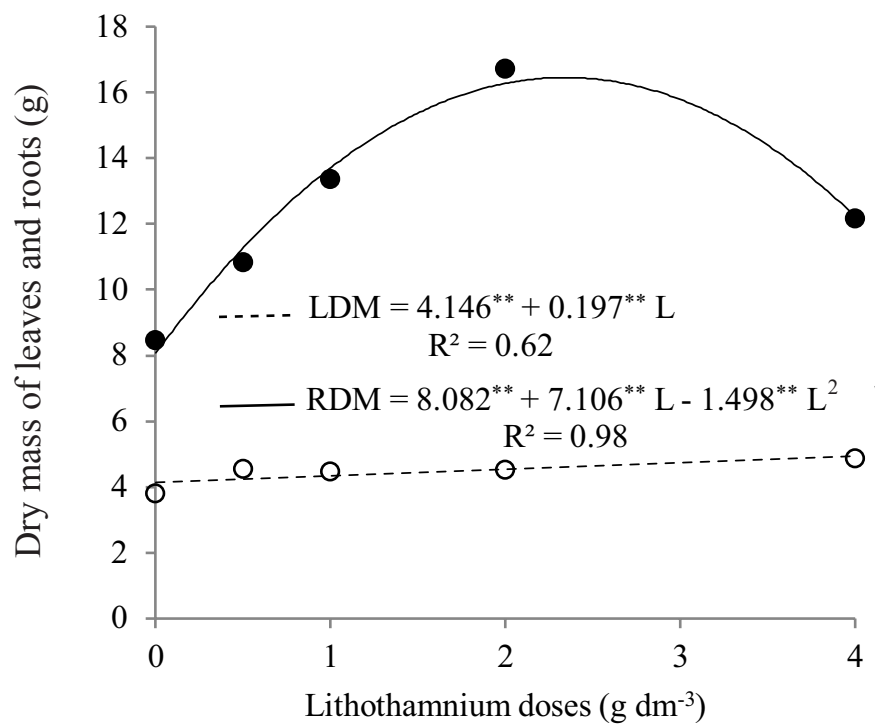

Figure 3. Dry matter of leaves (LDM) and roots (RDM) of bell pepper plants as a function of doses of lithothamnium

content of calcium, an element that is essential for the growth of meristems and required by the plant for cell elongation and division (Dechen \& Nachtigall, 2007). The absorption of the calcium present in the lithothamnium promotes the growth and functioning of the root apexes (Melo \& Furtini Neto, 2003).

For production, there were significant differences between the treatments for the number of fruits per plant and production of fruits. The number of fruits per plant was influenced only by irrigation management, while the production per plant and mean mass of fruits were influenced by irrigation and fertilization, separately. There was no significant effect for the interaction between the evaluated factors.

The number of fruits per plant linearly decreased by $16 \%$ with the reduction in soil water potential from -6 to $-60 \mathrm{kPa}$ (Figure 4). Frizzone et al. (2001) also observed reduction in the number of fruits of yellow bell pepper as a function of the reduction in the soil matric potential, reporting the highest number of fruits per plant with the irrigation management of $-15 \mathrm{kPa}$ and the lowest number for irrigation at $-65 \mathrm{kPa}$. Caixeta (1981), in a cultivation in the open field, observed that the total number of fruits of bell pepper increased with the increment in the amount of water applied and with the reduction in irrigation interval.

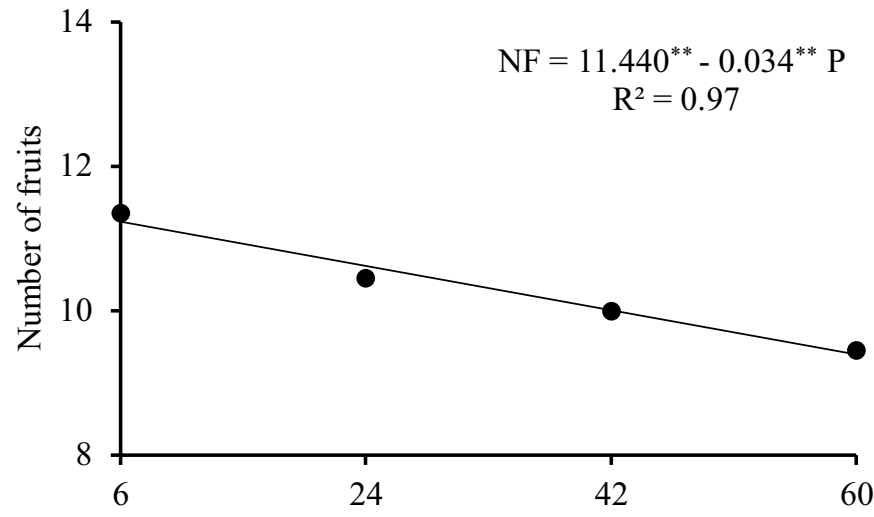

Soil water potential $(-\mathrm{kPa})$

Figure 4. Number of fruits (NF) per plant of bell pepper as a function of soil water potentials
The production of fruits per plant of bell pepper showed positive linear correlation with the soil water potentials (Figure $5 \mathrm{~A}$ ), with maximum production of $609.80 \mathrm{~g} \mathrm{plant}^{-1}$ for irrigation managed with the potential of $-6 \mathrm{kPa}$ and maximum of 395.87 $\mathrm{g} \mathrm{plant}^{-1}$ for plants irrigated at tension of $-60 \mathrm{kPa}$. The mean fruit production per plant of bell pepper, when cultivated in an organic cultivation system in Brazil, is 476 g plant $^{-1}$ (Negretti et al., 2010); therefore, the obtained results reinforce the importance of irrigation for achieving high yields of the crop, resulting in a probably economic viability.

For the doses of lithothamnium, the production of fruits per plant showed positive linear response and the highest production was $13 \%$ superior to that obtained in the absence of the fertilizer (Figure 5B). The lower increment in production can be related to the base saturation of the soil used as a substrate, which was above $50 \%$, resulting in smaller differences. Melo \& Furtini Neto (2003), evaluating lithothamnium as a corrective of soil acidity and source of nutrients for bean plants, observed positive effect of the fertilizer, and the maximum production was obtained with the application of the dose of $1.68 \mathrm{~g} \mathrm{dm}^{-3}$ in a Quartzarenic Neosol and with $5.68 \mathrm{~g} \mathrm{dm}^{-3}$ in a dystrophic Red Yellow Latosol.

In the estimation of the maximum economic efficiency of the fertilizer, the production of fruits per plant corresponding to $90 \%$ of the maximum was 491.26 g plant $^{-1}$, with the application of 0.54 $\mathrm{g} \mathrm{dm}^{-3}$ de lithothamnium. The value corresponds to a saving of approximately $87 \%$, indicating that low doses of lithothamnium are more adequate to optimize the cost/benefit ratio. Melo \& Furtini Neto (2003) also recommend the application of economic
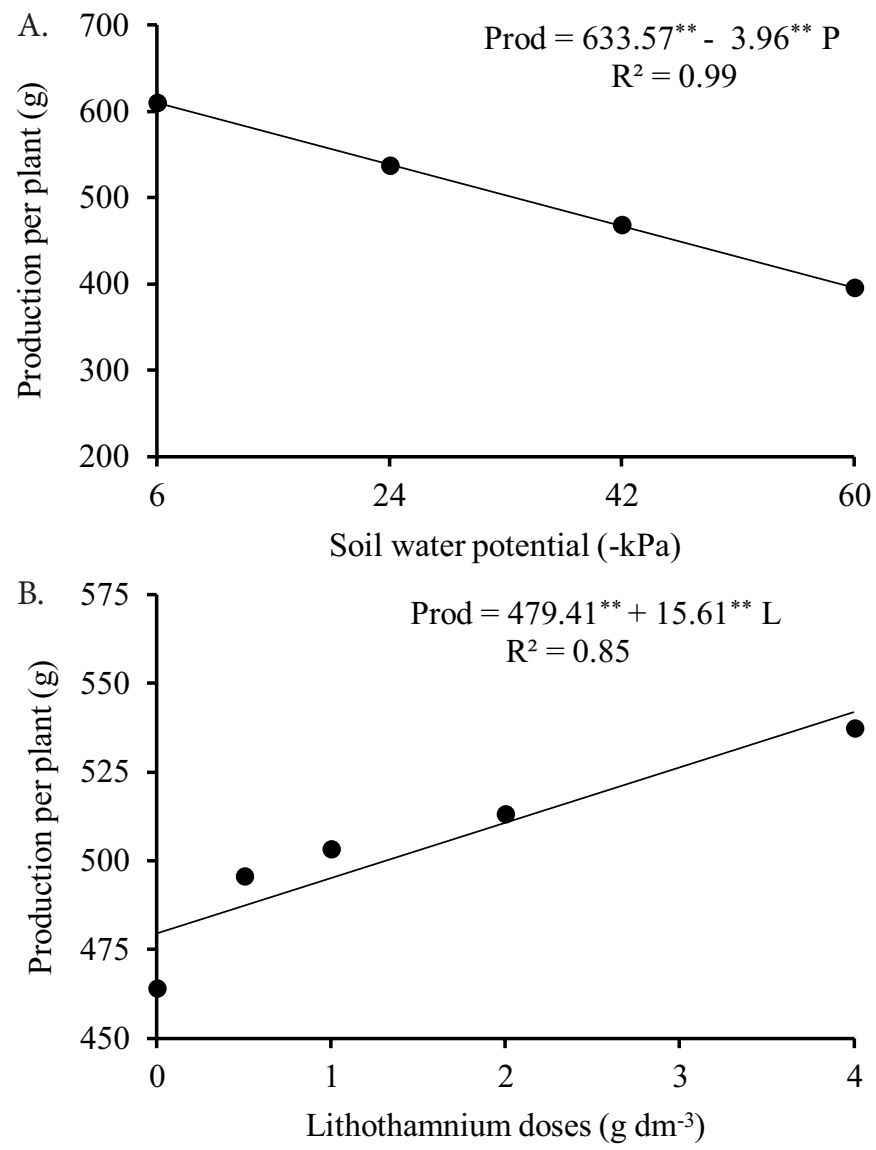

Figure 5. Production of fruits per plant (Prod) of bell pepper as a function of soil water potentials (A) and doses of lithothamnium (B) 
doses, since they estimated $51 \%$ of saving in relation to the dose for maximum production.

The higher mass of fruits harvested in bell pepper plants irrigated at $-6 \mathrm{kPa}$ (Figure 6A) possibly results from the growth of the pericarp due to the availability of water, which increases the turgor pressure of the cell (Lacerda et al., 2007), leading to a greater cell volume and, consequently, greater fruit mass. In bell pepper, cell division is limited at the beginning of fruit development and the growth is basically due to cell expansion (Lacerda et al., 2007). Therefore, under water deficit conditions, the water flow to the fruits is reduced and their size is compromised (Souza, et al., 2011; Cantuário et al., 2014). Carvalho et al. (2013) also observed that irrigation contributed to the increase in the mean mass of bell pepper fruits. Plants irrigated at $-15 \mathrm{kPa}$ produced fruits with mass $62.94 \%$ higher than that of fruits harvested in plants irrigated at $-60 \mathrm{kPa}$.

There was influence of the lithothamnium doses on the mean mass of bell pepper fruits (Figure 6B), which is due to the positive effects promoted by the lithothamnium, probably through the supply of calcium and other nutrients to the crop, which promotes higher capacity of the plants to produce fruits with greater mass. In addition, fruits with greater mass also show greater size and, therefore, are more attractive to the consumer.
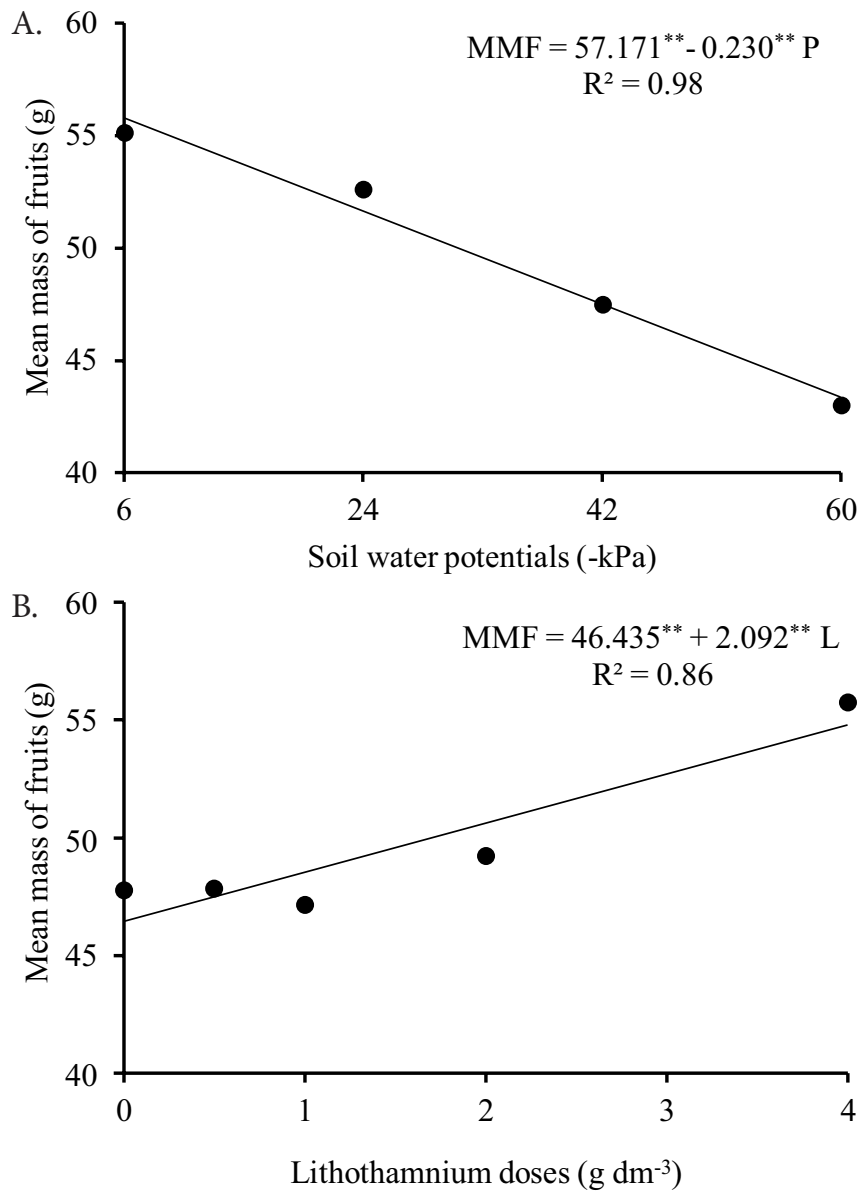

Figure 6. Mean mass of fruits (MMF) of bell pepper as a function of soil water potentials (A) and doses of lithothamnium (B)

\section{Conclusions}

1. In organic cultivation of bell pepper, the application of lithothamnium doses and irrigation management based on soil water potentials favor plant growth and increase fruit production.

2. The water deficit in the soil reduces bell pepper growth and production.

3. Soil water potential close to $-6 \mathrm{kPa}$ controlled at depth of $0.15 \mathrm{~m}$ and fertilization with lithothamnium dose of $0.54 \mathrm{~g} \mathrm{dm}^{-3}$ are indicated for the cultivation of bell pepper in organic system.

\section{Literature Cited}

Araújo, W. F.; Oliveira, G. A.; Carvalho, F. K.; Silva, W. M.; Cruz, P. L. S.; Maciel, F. C. S. Manejo da irrigação do meloeiro com base na evaporação do tanque classe A. Horticultura Brasileira, v.28, p.495499, 2010. http://dx.doi.org/10.1590/S0102-05362010000400020

Aquino, L. A.; Berger, P. G.; Neves, J. C. L.; Lima, P. C.; Quino, F. B. A. Parcelamento de fósforo em algodoeiro irrigado. Pesquisa Agropecuária Tropical, v.42, p.1-8, 2012. http://dx.doi.org/10.1590/ S1983-40632012000100001

Benincasa, M. M. P. Análise de crescimento de plantas: Noções básicas. 2.ed. Jaboticabal: Fundação Nacional de Ensino e Pesquisa, 2003. $41 \mathrm{p}$.

Caixeta, J. T. Efeito da lâmina de irrigação por gotejamento na cultura do pimentão. I - Produção de frutos maduros. Revista Ceres, v.28, p.40-51, 1981.

Cantuário, F. S.; Luz, J. M. Q.; Pereira, A. I. A.; Salomão, L. C.; Rebouças, T. N. H. Podridão apical e escaldadura em frutos de pimentão submetidos a estresse hídrico e doses de silício. Horticultura Brasileira, v.32, p.215-219, 2014. http://dx.doi.org/10.1590/S010205362014000200017

Carvalho, J. A.; Rezende, F. C.; Aquino, R. F.; Freitas, W. A.; Oliveira, E. C. Análise produtiva e econômica do pimentão-vermelho irrigado com diferentes lâminas, cultivado em ambiente protegido. Revista Brasileira de Engenharia Agrícola e Ambiental, v.15, p.569-574, 2011. http://dx.doi.org/10.1590/S1415-43662011000600005

Carvalho, K. S.; Koetz, M.; Polizel, A. C.; Cabral, E. A.; Silva, C. R. M. Cultivo de pimentão vermelho submetido à tensão de água no solo. Enciclopédia Biosfera, v.9, p.659-667, 2013.

Dechen, A. R.; Nachtigall, G. R. Elementos requeridos à nutrição de plantas. In: Novais, R. F.; Alvarez V., V. H.; Barros, N. F.; Fontes, R. L. F.; Cantarutti, R. B.; Neves, J. C. L. (ed.). Fertilidade do solo. Viçosa: SBCS/UFV, Cap.3, 2007. p.92-132.

Dias, G. T. M. Granulados bioclásticos - Algas calcárias. Brazilian Journal of Geophysics, v.18, p.307-318, 2010.

Frizzone, J. A.; Gonçalves, A. C. A.; Rezende, R. Produtividade do pimentão amarelo, Capsicum annuum L., cultivado em ambiente protegido, em função do potencial mátrico de água no solo. Acta Scientiarum, v.23, p.1111-1116, 2001.

Genuchten, M. T. van. A closed form equation for predicting the hydraulic conductivity of unsaturated soils. Soil Science Society of America Journal, v.44, p.892-898, 1980. http://dx.doi.org/10.2136/ sssaj1980.03615995004400050002x

Lacerda, C. F. de; Enéas Filho, J.; Pinheiro, C. B. Fisiologia vegetal. 1.ed. Fortaleza: UFC, 2007. 353p.

Leão, R. A. O.; Teixeira, A. S.; Canafístula, F. J. F.; Mesquita, P. E. G.; Coelho, S. L. Desenvolvimento de um dispositivo eletrônico para calibração de sensores de umidade do solo. Engenharia Agrícola, v.27, p.294-303, 2007. http://dx.doi.org/10.1590/S010069162007000100024 
Lima, E. M. C.; Matiolli, W.; Thebaldi, M. S.; Rezende, F. C.; Faria, M. A. Produção de pimentão cultivado em ambiente protegido e submetido a diferentes lâminas de irrigação. Revista Agrotecnologia, v.3, p.40-56, 2012. http://dx.doi.org/10.12971/2179-5959.v03n01a04

Melo, P. C.; Furtini Neto, A. E. Avaliação do lithothamnium como corretivo da acidez do solo e fonte de nutrientes para o feijoeiro. Ciência e Agrotecnologia, v.27, p.508-519, 2003. http://dx.doi. org/10.1590/S1413-70542003000300003

Negretti, R. R. D.; Bini, D. A.; Amaral, U.; Martins, C. R. Avaliação da adubação orgânica em pimentão Capsicun annum cultivado em sistema orgânico de produção sob ambiente protegido. Revista da Faculdade de Zootecnia, Veterinária e Agronomia, v.17, p. 27-37, 2010.
Santos, R. F.; Carlesso, R. Déficit hídrico e os processos morfológico e fisiológico das plantas. Revista Brasileira de Engenharia Agrícola e Ambiental, v.2, p.287-294, 1998. http://dx.doi.org/10.1590/18071929/agriambi.v2n3p287-294

Souza, A. P.; Pereira, J. B. A.; Silva, L. D. B.; Guerra, J. G. M.; Carvalho, D. F. Evapotranspiração, coeficientes de cultivo e eficiência do uso da água da cultura do pimentão em diferentes sistemas de cultivo. Acta Scientiarum Agronomy, v.33, p.15-22, 2011. http://dx.doi. org/10.4025/actasciagron.v33i1.5527

Taiz, L.; Zeiger, E. Fisiologia Vegetal. 3.ed. Porto Alegre: Artmed, 2004. 719p. 